\title{
Helping Students Develop Statistical Reasoning: Implementing a Statistical Reasoning Learning Environment
}

Joan Garfield, University of Minnesota, USA, e-mail: jbg@umn.edu

Dani Ben-Zvi, University of Haifa, Israel, e-mail:dbenzvi@univ.haifa.ac.il

\section{Summary}

This paper describes a model for an interactive, introductory secondary or tertiary-level statistics course that is designed to develop students' statistical reasoning. This model is called a "Statistical Reasoning Learning Environment" (SRLE) and is built on the constructivist theory of learning.

\section{Keywords}

Teaching; Active Learning; Statistical Reasoning; Introductory Statistics Course; Constructivism.

\section{The Challenge of Learning and Teaching Statistics}

Statistics education has been the focus for researchers in many disciplines, perhaps because statistical reasoning is used in many disciplines and provides so many interesting issues and challenges. A majority of these research studies (see Garfield and Ben-Zvi, 2007) suggest very different ways of teaching than traditional lectures, which is how most current statistics instructors learned this subject themselves. Leaving that familiar method to try active learning techniques can be quite challenging. This paper presents a model for an interactive, introductory secondary or tertiary-level statistics course that is designed to develop students' statistical reasoning. This model is called a "Statistical Reasoning Learning Environment" (SRLE) and is built on the constructivist theory of learning.

\section{Building on Constructivist Principles of Learning}

According to the constructivist theory of learning, people learn by constructing knowledge, rather than by receiving knowledge. In the most general sense, the contemporary view of learning in accordance with the constructivist theory is that new knowledge and understandings are based on the existing knowledge and beliefs we 
already have and are grounded in our experiences (e.g., Cobb, 1994; Piaget, 1978; Vygotsky, 1978). We learn by doing. And when we learn, our previous knowledge does not go away; it is integrated with the new knowledge.

The implication of current theories of learning is that good instructional practice consists of designing learning environments that stimulate students to construct knowledge. This involves activities that provide students many opportunities to think, reason, and reflect on their learning, as well as discussing and reflecting with their peers. It does not mean that teachers should never "tell" students anything directly and instead should always allow them to construct knowledge for themselves. Rather it means that learning is enhanced when teachers pay attention to the knowledge and beliefs that learners bring to a learning task, use this knowledge as a starting point for new instruction, and monitor students' changing conceptions as instruction proceeds.

It is usually easier to prepare a lecture than it is to design a learning environment, where students engage in activities and discussions and/or collaborative projects, supported by technological tools. While the first approach is teacher centered: "what is it I want to tell my students," "what material do I want to cover," etc., the second approach is more student-centered: "what can I do to promote students learning," "how can I engage students in learning, hands-on activities, developing reasoning, discussing ideas, working in teams," etc. According to this latter approach, the teacher is cast as an instructional coach, a co-learner, an enculturator, or a facilitator, rather than as a conduit of knowledge in a teacher-centered classroom.

The main reason to change from a teacher-centered to a student-centered approach is that the second approach is more effective in helping students build a deeper understanding of statistics and to be able to transfer what they have learned in subsequent classes or in the real world. One problem with the "teaching is telling" approach is that students rarely have a chance to develop a deep understanding of what they have "learned," and quickly forget it after they complete a course.

\section{A Statistical Reasoning Learning Environment (SRLE)}

The SRLE is an effective and positive statistics classroom that develops in students a deep and meaningful understanding of statistics and helps students develop their ability to 
think and reason statistically. This approach is called a learning environment because it is the interactive combination of text materials, class activities and culture, discussion, technology, teaching approach, and assessment. This model is based on six principles of instructional design described by Cobb and McClain (2004):

1. Focus on developing central statistical ideas rather than on presenting set of tools and procedures.

2. Use real and motivating data sets to engage students in making and testing conjectures.

3. Use classroom activities to support the development of students' reasoning.

4. Integrate the use of appropriate technological tools that allow students to test their conjectures, explore and analyze data, and develop their statistical reasoning.

5. Promote classroom discourse that includes statistical arguments and sustained exchanges that focus on significant statistical ideas.

6. Use assessment to learn what students know and to monitor the development of their statistical learning as well as to evaluate instructional plans and progress.

\section{Focus on Developing Central Statistical Ideas (Content)}

There are several key statistical ideas that we would like all students to understand at a deep conceptual level. These ideas serve as overarching goals that direct teaching and motivate and guide students' learning. These include data, distribution, center and variability, for example.

While most textbooks present material in a structure based on a logical analyses of the content, students often see the content as a sequential set of tools and procedures and do not see how the concepts are interrelated. For example, learning about distribution early in a course is rarely connected to the ideas of sampling distributions later in a course. Garfield and Ben-Zvi (in press) advocate a focus on these key ideas and the interrelations among them and suggest ways to present them throughout a course, revisiting them in different contexts, illustrating their multiple representations and interrelationships, and helping students recognize how they form the supporting structure of statistical knowledge. 


\section{Use Real and Motivating Data}

Data are at the heart of statistical work, and data should be the focus for statistical learning as well (Franklin and Garfield, 2006). Throughout a course, students need to consider methods of data collection and production and how these methods affect the quality of the data and the types of analyses that are appropriate. Interesting data sets motivate students to engage in activities, especially ones that ask them to make conjectures about a data set before analyzing it.

\section{Use Classroom Activities to Develop Students' Statistical Reasoning}

An important part of the SRLE is the use of carefully designed, research-based activities that promote student learning through collaboration, interaction, discussion, data, and interesting problems (e.g., Bransford, Brown, \& Cocking, 2000). The positive effects of active learning have been found for short-term mastery, long-term retention, or depth of understanding of course material; acquisition of critical thinking or creative problemsolving skills; formation of positive attitudes toward the subject being taught, and level of confidence in knowledge or skills.

There are two different models of class activities in the SRLE. The first engages students in making conjectures about a problem or a data set. This method involves discussing students' conjectures, gathering or accessing the relevant data, using technology to test their conjectures, discussing the results, and then reflecting on their own actions and thoughts. The second type of activity is based on cooperative learning, where two or more students are given questions to discuss or a problem to solve as a group. For more examples of cooperative learning in statistics, see Roseth, Garfield and Ben-Zvi (in press).

\section{Integrate the Use of Appropriate Technological Tools}

There are a variety of technological tools to support development of student understanding and reasoning (e.g., computers, graphing calculators, Internet, statistical software, and Web applets). Students no longer have to spend time performing tedious calculations and can focus instead on the more important task of learning how to choose appropriate analytic methods and how to interpret results. Technological tools are used 
not only to generate statistics, graph data, or analyze data, but also to help students visualize concepts and develop an understanding of abstract ideas through simulations. For examples of innovative tools and ways to use these tools to help develop students' reasoning, see Chance, Ben-Zvi and Garfield (2007).

\section{Promote Classroom Discourse}

Traditional statistics classes usually did not have much discourse, "giving" information through lectures and asking questions to "get" some answers. This is different from the kind of dialogue where students respond to each other's questions and learn to question each other as well as defend their answers and arguments. In the SRLE, the use of activities and technology allows for a new form of classroom discourse. Cobb and McClain (2004) describe the characteristics of effective classroom discourse in which statistical arguments explain why the way in which the data have been organized gives rise to insights into the phenomenon under investigation; students engage in sustained exchanges that focus on significant statistical ideas.

It can be very challenging to create a SRLE with classroom discourse that enables students to engage in discussions in which significant statistical issues emerge and where arguments are presented and their meaning is openly negotiated. Some suggestions for developing classroom discourse include:

1. Use questions that encourage students to speculate and think and do not necessarily have one right answer. For example, asking students to reason about what might be compelling evidence that a student can actually distinguish between two brands of soda in a blind taste test.

2. Require students to explain their reasoning and justify their answers. Then ask other students if they agree or disagree and why.

3. Create a classroom climate where students feel safe expressing their views, even if they are tentative. This can be done if teacher encourage students to express their conjectures, and asking other students to comment on these conjectures, and allowing students to test some of these conjectures using tools and software, rather than telling them whether they are right or wrong. 
For more information and practical advice about leading and managing discussions, see McKeachie and Svinicki (2006).

\section{Use Alternative Assessment}

In recent years, many alternative forms of assessment are used in statistics classes. In addition to quizzes, homework and exams, many teachers use student's statistical projects as a form of authentic assessment. Other forms of alternative assessment are also used to assess students' statistical literacy (e.g., critique a graph in a newspaper), their reasoning (e.g., write a meaningful short essay), or provide feedback to the instructor (e.g., minute papers).

Assessments need to be aligned with learning goals, focusing on understanding key ideas and not just on skills, procedures, and computed answers. This can be done with formative assessments used during a course (e.g., quizzes, small projects, or observing and listening to students in class) as well as with summative evaluations (course grades). Useful and timely feedback is essential for assessments to lead to learning. Types of assessment may be more or less practical in different types of courses. However, it is possible, even in large classes, to implement good assessments.

The ARTIST Website (https://app.gen.umn.edu/artist) offers an item bank of more than a thousand items that have been designed to measure students' statistical literacy, reasoning and thinking, many of which are in forced choice format but provide examples of more reasoning-based items.

\section{A Closer Look at the SRLE}

To better understand the SRLE, we compare it to a "traditional" class.

\section{A "Traditional” Class}

The students come to class, with no anticipation of what they will learn ready to copy down what the instructor has to say. The instructor presents a lecture that includes examples, some data analysis, perhaps some demonstrations. The students listen, take notes, and perhaps ask questions. They leave class with a homework assignment that uses information from the class they just attended. They go home, try to solve the problems by 
looking back at their notes or looking up worked examples in the textbook, often getting frustrated if they don't find an exact match.

Now picture a very different kind of class.

\section{A SRLE Class}

The students know that they have to prepare for class by reading a few pages in the textbook using study questions to guide their reading and note taking. Students are therefore prepared to come to class with a preliminary exposure to words and techniques, a low level of statistical literacy. Class begins with a short summary of what was learned in the previous class, and students are asked if they have questions on the previous class or on the assigned reading. Students ask some questions that are answered by other students and/or the instructor. The instructor rarely answers a question directly but often asks students, "What do you think?" and if another student gives an answer asks, "Do you agree with this answer? Why?"

Now the class is ready to begin the first activity. A question is given to the students such as "Do you think that female college students spend more time on cell phones than male students?" Additional questions are asked such as "What are typical amounts of time students spend per call on their cell phones?" or "What type of distribution would you expect to see for cell phone usage?"

Students form small groups to discuss these questions and sketch possible distributions, and then share and compare their conjectures and reasoning with the class. The students move to computers and access a data set containing this information that has previously been gathered about the students in the class using an online student survey. Working in pairs, students generate graphs and statistics to answer the questions on cell phone use. Students may discuss appropriate measures of center and spread for the data, revisiting those ideas from previous lessons. They may notice outliers in the data and discuss what to do: How to find out if they are legitimate values or errors, what happens to the graphs and statistics if those extreme values are removed?

The teacher's role in this class is to present the problem, guide the discussion, anticipate misconceptions or difficulties in reasoning, make sure students are engaged and on task 
and not experiencing any difficulties. The teacher has to know when to end discussions, when to correct mistakes, and how to provide a good summary for the activity using the work students have done, so students can appreciate what they learned from the activity. At the end of class, after the wrap-up discussion and summary, students may be asked to complete a brief assessment task, providing the teacher with feedback on their learning for that class.

The contrasts in the teacher's role, student's role and responsibility, and other aspects of the course are illustrates in Table 1.

Table 1. Major changes between a "traditional" statistics class and a SRLE class.

\begin{tabular}{|c|c|c|}
\hline $\begin{array}{l}\text { Aspect of the } \\
\text { Course }\end{array}$ & "Traditional" Statistics Class & SRLE Class \\
\hline Focus of course & $\begin{array}{l}\text { Skills and procedures, covering } \\
\text { content. }\end{array}$ & $\begin{array}{l}\text { Big ideas, developing statistical } \\
\text { reasoning and thinking. }\end{array}$ \\
\hline Role of textbook & $\begin{array}{l}\text { Use for examples or homework } \\
\text { problems and to review for test. }\end{array}$ & $\begin{array}{l}\text { Read and take notes to prepare for } \\
\text { class. }\end{array}$ \\
\hline Center & Teacher centered. & Student centered. \\
\hline Role of the teacher & $\begin{array}{l}\text { Delivers knowledge by telling } \\
\text { and explaining. }\end{array}$ & $\begin{array}{l}\text { Facilitates developing of knowledge } \\
\text { through discussion and activities. }\end{array}$ \\
\hline Role of technology & $\begin{array}{l}\text { To compute or check answers, } \\
\text { construct graphs. }\end{array}$ & $\begin{array}{l}\text { To explore data, illustrate concepts, } \\
\text { generate simulations, test } \\
\text { conjectures, and collaborate. }\end{array}$ \\
\hline Discourse & Teacher answers questions. & $\begin{array}{l}\text { Teacher poses questions and guides a } \\
\text { discussion. Students present } \\
\text { arguments, answer other students' } \\
\text { questions, and are asked if they agree } \\
\text { or disagree with answers. Peer and } \\
\text { instructor feedback is provided. }\end{array}$ \\
\hline Data & $\begin{array}{l}\text { Small data sets to illustrate and } \\
\text { practice procedures. }\end{array}$ & $\begin{array}{l}\text { Rich, real data sets to engage } \\
\text { students in thinking and reasoning } \\
\text { and making conjectures. Many data } \\
\text { sets are generated by the students } \\
\text { from surveys and experiments. }\end{array}$ \\
\hline Assessment & $\begin{array}{l}\text { Focuses on computations, } \\
\text { definitions and formulas; on } \\
\text { short answers and multiple } \\
\text { choice tests. Often only } \\
\text { midterm and final tests are } \\
\text { given. }\end{array}$ & $\begin{array}{l}\text { Uses a variety of methods, assesses } \\
\text { reasoning and thinking. Formal and } \\
\text { informal assessment is an integral } \\
\text { part of learning and is aligned with } \\
\text { learning methods and goals. Students } \\
\text { may be asked to explain their } \\
\text { reasoning and justify their } \\
\text { conclusions. }\end{array}$ \\
\hline
\end{tabular}




\section{Moving to a SRLE}

We have presented two extremes: a "traditional" class and a class based on the SRLE. The contrast between these two approaches is large, and it is apparent that even an eager and enthusiastic teacher who wants to move from a more traditional approach to a more SRLE approach is faced with many challenges. These challenges include students, colleagues, and institution, as well as challenges inherent in instructors. These challenges are examined and addressed in Garfield and Ben-Zvi (in press).

The first step in moving towards the SRLE is to see how one's current course and materials align with the components of a SRLE and then pick a starting point. For some sample activities see the AIMS Website (http://www.tc.umn.edu/ aims). Careful and steady change over a period of time may lead to a successful implementation of a SRLE in a statistics course, rather than trying a radical, all at once change.

\section{Summary}

A Statistical Reasoning Learning Environment is quite different than a traditional lecturebased classroom, but it may also be quite different from many statistics classes that use some activities, real data sets, and technology tools. The six principles outlined earlier are key elements in developing a class where students are engaged in making and testing conjectures using data, discussing and explaining statistical reasoning, and focusing on the important big ideas of statistics.

\section{References}

Bransford, J., Brown, A.L., \& Cocking, R.R. (Eds.) (2000). How people learn: Brain, mind, experience, and school. Washington, DC: National Academy Press.

Chance, B., Ben-Zvi, D., Garfield, J., \& Medina, E. (2007, October). The role of technology in improving student learning of statistics. Technology Innovations in Statistics Education Journal, 1(1). Retrieved November 15, 2007, from http://repositories.cdlib.org/uclastat/cts/tise/vol1/iss1/art2/

Cobb, P. (1994). Where is the mind? Constructivist and sociocultural perspectives on mathematical development. Educational Researcher, 23(7), 13-20. 
Cobb, P., \& McClain, K. (2004). Principles of instructional design for supporting the development of students' statistical reasoning. In D. Ben-Zvi \& J. Garfield (Eds.), The challenge of developing statistical literacy, reasoning, and thinking (pp. 375396). Dordrecht, The Netherlands: Kluwer Academic Publishers.

Franklin, C., \& Garfield, J. (2006). The Guidelines for Assessment and Instruction in Statistics Education (GAISE) project: Developing statistics education guidelines for pre K-12 and college courses. In G.F. Burrill, (Ed.), Thinking and reasoning about data and chance: Sixty-eighth NCTM Yearbook (pp. 345-375). Reston, VA: National Council of Teachers of Mathematics.

Garfield, J., \& Ben-Zvi, D. (2007). How students learn statistics revisited: A current review of research on teaching and learning statistics. International Statistical Review, 75(3), 372-396.

Garfield, J., \& Ben-Zvi, D. (in press). Developing Students' Statistical Reasoning: Connecting Research and Teaching Practice. Dordrecht, The Netherlands: Springer.

McKeachie, W.J., \& Svinicki, M. (2006). Teaching tips: Strategies, research, and theory for college and university teachers (12 ${ }^{\text {th }}$ Edition). Boston: Houghton Mifflin.

Piaget, J. (1978). Success and understanding. Cambridge MA: Harvard University Press.

Roseth, C.J., Garfield, J.B., \& Ben-Zvi, D. (in press). Collaboration in learning and teaching statistics. Journal of Statistics Education.

Vygotsky, L. (1978). Mind in society. Cambridge, MA: Harvard University Press. 